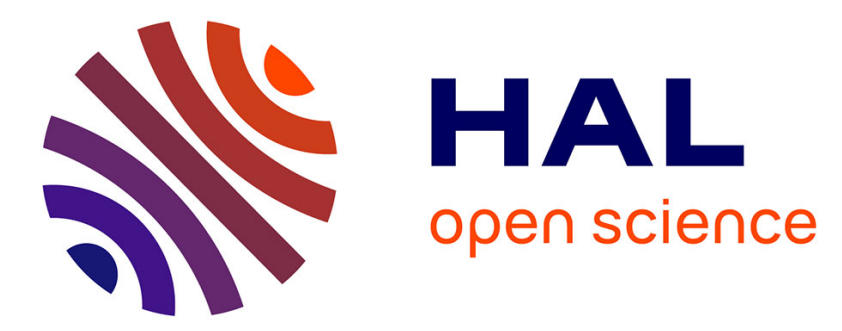

\title{
Allometric relationships for intertidal macroalgae species of commercial interest
}

Doriane Stagnol, Marine Macé, Christophe Destombe, Dominique Davoult

\section{To cite this version:}

Doriane Stagnol, Marine Macé, Christophe Destombe, Dominique Davoult. Allometric relationships for intertidal macroalgae species of commercial interest. Journal of Applied Phycology, 2016, pp.1-5. 10.1007/s10811-016-0860-1. hal-01318013

\section{HAL Id: hal-01318013 https://hal.sorbonne-universite.fr/hal-01318013}

Submitted on 19 May 2016

HAL is a multi-disciplinary open access archive for the deposit and dissemination of scientific research documents, whether they are published or not. The documents may come from teaching and research institutions in France or abroad, or from public or private research centers.
L'archive ouverte pluridisciplinaire HAL, est destinée au dépôt et à la diffusion de documents scientifiques de niveau recherche, publiés ou non, émanant des établissements d'enseignement et de recherche français ou étrangers, des laboratoires publics ou privés. 


\section{Allometric relationships for intertidal macroalgae species of commercial interest}

Doriane Stagnol $^{\mathrm{a}, \mathrm{b}}$, Marine Macé ${ }^{\mathrm{a}, \mathrm{b}}$, Christophe Destombe ${ }^{\mathrm{a}, \mathrm{c}}$, Dominique Davoult ${ }^{\mathrm{a}, \mathrm{b}}$

${ }^{a}$ Sorbonne Universités, UPMC Univ Paris 6, Station Biologique, Place Georges Teissier, F-29682

Roscoff, France

${ }^{\mathrm{b}}$ CNRS, UMR 7144 AD2M, Place Georges Teissier, F-29682, Roscoff, France

c CNRS, UMI 3614 EBEA, Place Georges Teissier, F-29682, Roscoff, France

* Corresponding author: doriane.stagnol@gmail.com Tel: +332982923 23 Fax: +33298292324

\section{Abstract}

The demand for seaweeds has intensified in recent decades and will most certainly continue to expand. Several methods exist to evaluate the biomass of seaweeds in the field but most of them are destructive. The objectives of this study were (1) to develop and evaluate allometric equations for estimating seaweed biomass in the field for some harvested species, and (2) to provide uniform calculated dry/wet biomass ratios to estimate the relative water content of these seaweeds. Sampling and measurements of more than 350 seaweeds individuals were carried out for 8 species of commercial interest. Our models were fitted for both power and linear equations and were tested for different explanatory variables. While the power equation was found to be the best for predicting biomass of all species, we found that the best descriptive biometric variable varies according to seaweed morphology. Species with a bushy morphology were best described by the volume, while long stringy species were best described by the length and flat species by the surface. This study attempts to provide nondestructive tools that could be used by professional seaweed harvesters, their employers as well as scientists and public regulators, to assess the harvest potential of a field of seaweed in a nondestructive approach.

Keywords: biometrics, biomass, allometry, harvesting

\section{Acknowledgements}

The authors thank all the people who helped carry out the fieldwork. Our study was funded by the ALGMARBIO project, InitiativeBioBretagne (IBB), FranceAgriMer (National Institute of Agricultural and Marine Products), the Brittany Regional Council, the Côte d'Armor Departmental Council, the European Fisheries Fund (EFF), and benefited from the support of the French Government run by the National Research Agency and with regards to the investment expenditure programme IDEALG ANR-10-BTBR-04. 


\section{Introduction}

Seaweed diversity and community structure are highly impacted and threatened by physical and/or anthropic forcing such as climatic changes (Airoldi and Beck 2007; Mangialajo et al. 2008). These continued stressors cause the fragmentation and loss of canopy-forming algae worldwide (Connell et al. 2008; Airoldi et al. 2008), and even could lead to their extinction (Estes et al. 1989). Besides producing a valuable crop to the seaweed harvesters, macroalgae plays an important role in the primary production of nearshore ecosystems (Golléty et al. 2008; Migné et al. 2015). Within this context of increasing pressures, one can wonder about the effects of the loss of canopy-forming algae on primary production and on carbon and nitrogen biochemical cycles. Accurate and efficient estimation of biomass in such populations is central to understand and monitor their net contribution in providing these ecosystem services.

Ecologists, botanists and foresters estimate biomass for a wide range of purposes, such as assessment of crop value, site productivity, as well as nutrient recycling. Destructive sampling has generally been used to obtain an accurate measure of biomass at a particular sampling point, including in seaweed populations (Mathieson and Guo 1992; Vadas, Sr. et al. 2004). However, these destructive approaches can have short and long-term consequences on the associated ecosystem, including decrease in invertebrate abundance and richness (BenedettiCecchi et al. 2001; Watt and Scrosati 2013), replacement by grazers or turfs (Perkol-Finkel and Airoldi 2010), or reduction in algal biomass and primary productivity (Golléty et al. 2008; Tait and Schiel 2011). In order to reduce these effects, nondestructive methods were developed to answer specific questions in plants (Niklas and Enquist 2002; Sack et al. 2003; Scrosati et al. 2005; Mccarthy and Enquist 2007; Poorter et al. 2012). Without losing their scientific rigor, the use of nondestructive sampling methods permits the absence of laboratory work, simplifying data processing and reducing the total monitoring costs. One of these 
nondestructive methods is based on fitting so-called allometric equations to convert field inventory data to biomass estimates (Chave et al. 2005; Jonson and Freudenberger 2011; Paul et al. 2013). In seaweeds, this method was mainly applied in population dynamics of red and brown algae (Åberg 1990; Lindgren et al. 1998; Engel et al. 2001) or to estimate growth during two sampling events (Vaz-Pinto et al. 2014). Allometric equations are particularly useful to evaluate biomass allocation pattern (i.e. the relative amount of biomass present in the various organs; Niklas and Enquist 2002), to measure the temporal evolution of the biomass on a specific field, or to adjust the harvesting pressure according to biomass estimates at a given time. Biological ratios are often used in the literature to standardize biological data. Dry/wet biomass ratios, are generally used to estimate the relative water content in plants and to homogenize the parameters found in the literature (which may be expressed either in dry or wet biomass). Moreover, this ratio can be used by professional seaweed harvesters (or their employers) that are required, under French law, to report monthly the quantities of algae they have harvested, in fresh biomass.

Seaweeds are a polyphyletic group that displays a wide diversity of life cycles and morphologically diverse thalli with variable growth rates. Because seaweeds species are highly diverse, estimation of their biomass through allometric relationships is a challenging task. The overall objective of this study was to develop and evaluate allometric equations for estimating the biomass in the tree main groups of harvested seaweed (three red algal species (Chondrus crispus, Mastocarpus stellatus, Palmaria palmata), four brown algal species (Fucus serratus, Fucus vesiculosus, Himanthalia elongata, Saccharina latissima) and one green algal species (Ulva sp.). We also provide uniform calculated dry/wet biomass ratios to estimate the relative water content of seaweeds. 


\section{Materials and methods}

Samples were collected in Brittany (Northern France) where more than $80 \%$ of macroalgae are harvested in France. We pooled datasets obtained across several years (2004 to 2015), in order to create sufficiently powered samples that are large enough to allow for meaningful analysis. An attempt was made to obtain samples representative of the full length range of each species. All datasets were obtained between March and November, the time when most of the biomass is extracted due to greater harvestable biomass and legal harvest period.

In this study, we measured individuals, as defined by Scrosati (2005). The whole thallus corresponding to all the fronds that arise from one holdfast was measured for clonal seaweeds (Chondrus crispus, Mastocarpus stellatus, Palmaria palmata) and the whole thallus corresponding to the only upright that arises from one holdfast was measured for unitary seaweeds (Fucus serratus, F. vesiculosus, Himanthalia elongata and Ulva sp.). For each individual, the maximal length (L) and the dry biomass (DW), after drying at $60^{\circ} \mathrm{C}$ for $48 \mathrm{~h}$, were recorded. For some species, the maximal circumference $(\mathrm{C})$, the maximal width $(\mathrm{w})$ and the fresh biomass (FW) were also recorded, prior to the drying.

\section{Length-biomass relationships}

Allometric length-biomass equations were obtained by regressing dry biomass on maximal length $(\mathrm{L})$, maximal circumference $(\mathrm{C})$, volume $\left(\mathrm{LC}^{2}\right)$, or surface $(\mathrm{Lw})$. We wrote the models using $\mathrm{R}$ to obtain both linear (Eq 1) and power law equation (Eq 2):

$$
\mathrm{DW}=\mathrm{a} \times \mathrm{X}+\mathrm{b}
$$

$$
\mathrm{DW}=\mathrm{a} \times \mathrm{X}^{\mathrm{b}}
$$

where DW = dry biomass $(\mathrm{g}), \mathrm{X}=$ variable or combination of variables $\left(\mathrm{L}, \mathrm{C}, \mathrm{LC}^{2}, \mathrm{LW}\right)$, and a and $b$ are constants. Then we selected for each species the best model using the Akaike 
information criterion (AIC) and the determination coefficient $\left(\mathrm{R}^{2}\right)$. The best statistical model minimizes the value of AIC and maximizes the value of $\mathrm{R}^{2}$. It is important to note that we also determined the length-biomass relationship of $C$. crispus and $M$. stellatus blended, because in the field they usually form a mixed canopy that could not be harvested separately. We also made a seasonal distinction for $H$. elongata by calculating the allometric equation for only individuals harvested from March to June on one side (i.e. the harvestable individuals truly harvested) and the allometric equation for all the individuals harvested between March and October on the other side. After June or July, large individuals are no more harvested because they are thick and grainy, thus less appealing for human consumption. Essentially, the first equation (March-June) should be used by professional seaweed harvesters while the second equation (March-October) could be better suited for scientist interest.

All statistical analyses were carried out with the $\mathrm{R}$ software package (http://www.rproject.org/).

\section{Mean water content}

The mean water content of the algae was determined by weighing before and after drying. In order to quantify the relationship between fresh biomass and dry biomass, we used standardized major axis (SMA) regression (also referred to as reduced major axis regression). This method is more appropriate than least-squares regression for estimating the line of best fit for the relationship between two variables (Warton et al. 2006). The obtained fitted line does not change if the roles of "predictor" and "response" variables are switched; in contrast, ordinary least squares regression yields a different fitted line if the $\mathrm{y}$-axis and $\mathrm{x}$-axis are switched (Warton et al. 2006).

\section{Results and discussion}


131 Relationships between mass (expressed as dry biomass) and biometrics were established. We 132 tested linear and power models for more than 350 individuals from 8 different species. For 133 each model, we tested several explanatory variables: L, C, and $\mathrm{LC}^{2}$ for $C$. crispus, P. palmata F. serratus, and F. vesiculosus; L, w and Lw for Ulva sp.; and $\mathrm{L}$ for $H$. elongata and S. latissima. The 10 selected length-biomass relationships are shown in Fig. 1 and their respective parameters are given in Table 1 . These inclusive relationships were all expressed as a power model. The best descriptive biometric variable varied according to the seaweed morphology. Species with a bushy morphology were best described by the volume (LC2), while long stringy species were best described by the length (L) and flat species by the surface (Lw). All the relationships of the seaweed species analysed in this paper were highly significant $\left(0.77<\mathrm{R}^{2}<0.96\right)$ and could consequently be reliably applied (Table 1$)$. Besides,

142 Gevaert et al. (2001) provided an allometric equation for the species S. latissima with a 143 scaling exponent really close $(b=1.357)$ to the one we calculated $(b=1.358)$. Allometric equations (DW $=\mathrm{a} \times \mathrm{X}^{\mathrm{b}}$ ) were not found for any other species studied.

Nondestructive methods of seaweed biomass estimation have successfully been applied in the past. For example Scrosati and DeWreede (1997) have successfully applied nondestructive methods to estimate stand biomass in a biomass-density study that was based on the fronds and not on the individuals of one species (Mazzaella cornucopiae).

The two allometric equations obtained for $H$. elongata showed different allometric parameter values, with the scaling exponent (b) of harvestable individuals (March-June) being lower (57\%) than the one calculated with all individuals (March-October). This difference reveals an ontogenetic shift, partly because in late summer and autumn, individuals of $H$. elongata get 
153

154

155

156

157

158

159

160

161

162

163

164

165

166

167

168

169

170

171

172

173

174

175

thicker which increases their biomass, become not consumable and so are no more harvested after June-July.

With the exception of $H$. elongata, seasonal variations were not completely taken into account (no sampling in winter), which may potentially cause a difference between the predicted DW and the observed DW at the individual scale, due to differences in tissue density (Åberg 1990). However, as stated above, most of the seaweed harvesting occurs between March and November, which corresponds to the period when we made our samples. Also, we do believe than any potential biases should be reduced at the scale of the quadrat or seaweed field. Therefore, these tools can be applied to large populations and are relevant to provide accurate estimates of the standing biomass of a seaweed field, in a rapid and nondestructive way.

\section{Development of ratios for estimating water content}

Relationships between DW and FW were expressed as a linear relation and were also highly significant $\left(\mathrm{R}^{2}>0.90\right)$. They showed that mean water content ranged from $71.7 \%(M$. stellatus) to $88.5 \%$ (S. latissima) (Table 2). While DW:FW ratios may vary depending on the season, our results are quite consistent with those found in the literature: Scrosati (2006) described a mean water content of $76.1 \%$ for $C$. crispus, $79.3 \%$ for $F$. vesiculosus and $87.6 \%$ for S. latissima; Gevaert et al. (2001) found a mean water content of $89 \%$ for S. latissima; and Alveal and Ponce (1997) estimated a mean water content of $72 \%$ for M. stellatus. Due to technical, commercial and infrastructural reasons, harvesters dry some harvested algae prior to weighing them, and then convert the dry biomass into fresh biomass with a ratio that is specific to each harvester or employer. These ratios are often confidential and may lead to over- or underestimate the quantities of algae that are actually harvested. Here we attempt to 
176 provide uniform and rigorously calculated ratios that could be used by all the professional 177 seaweed harvesters and their employers.

178 Global environment change coupled to the increased demand for seaweeds are likely to exert 179 some significant pressure on the standing seaweed biomass. The relationships established in 180 the study will provide a basis for future studies to estimate more easily and by a 181 nondestructive way the biomass of seaweed populations. 


\section{References}

Åberg P (1990) Measuring size and choosing category size for a transition matrix study of the seaweed Ascophyllum nodosum. Mar Ecol Prog Ser 63:281-287

Airoldi L, Balata D, Beck MW (2008) The Gray Zone: Relationships between habitat loss and marine diversity and their applications in conservation. J Exp Mar Biol Ecol 366:8-15

Airoldi L, Beck MW (2007) Loss, status and trends for coastal marine habitats of Europe. Oceanogr Mar Biol 45:345-405

Alveal K, Ponce F (1997) Determination of water content in seaweeds. Gayana Oceanol 5:111

Benedetti-Cecchi L, Pannacciulli F, Bulleri F, et al (2001) Predicting the consequences of anthropogenic disturbance: large-scale effects of loss of canopy algae on rocky shores. Mar Ecol Prog Ser 214:137-150

Chave J, Andalo C, Brown S, et al (2005) Tree allometry and improved estimation of carbon stocks and balance in tropical forests. Oecologia 145:87-99

Connell S, Russell B, Turner D, et al (2008) Recovering a lost baseline: missing kelp forests from a metropolitan coast. Mar Ecol Prog Ser 360:63-72

Engel C, Åberg P, Gaggiotti OE, et al (2001) Population dynamics and stage structure in a haploid-diploid red seaweed, Gracilaria gracilis. J Ecol 89:436-450

Estes JA, Duggins DO, Rathbun GB (1989) The Ecology of Extinctions in Kelp Forest Communities. Conserv Biol 3:252-264

Gevaert F, Davoult D, Creach A, et al (2001) Carbon and nitrogen content of Laminaria saccharina in the eastern English Channel: biometrics and seasonal variations. J Mar Biol Assoc UK 81:727-734

Golléty C, Migné A, Davoult D (2008) Benthic metabolism on a sheltered rocky shore: role of the canopy in the carbon budget. J Phycol 44:1146-1153

Jonson JH, Freudenberger D (2011) Restore and sequester: estimating biomass in native Australian woodland ecosystems for their carbon-funded restoration. Aust J Bot 59:640-653

Lindgren A, Bouza N, Åberg P, Sosa PA (1998) Spatial and temporal variation in distribution of Gelidium canariensis (Rhodophyta) from natural populations of the Canary Islands. J Appl Phycol 10:273-278

Mangialajo L, Chiantore M, Cattaneo-Vietti R (2008) Loss of fucoid algae along a gradient of urbanisation, and structure of benthic assemblages. Mar Ecol Prog Ser 358:63-74

Mathieson AC, Guo Z (1992) Patterns of fucoid reproductive biomass allocation. Br Phycol J 27:271-292 
Mccarthy MC, Enquist BJ (2007) Consistency between an allometric approach and optimal partitioning theory in global patterns of plant biomass allocation. Funct Ecol 21:713720

Migné A, Delebecq G, Davoult D, Spilmont N, Menu D, Gevaert F (2015) Photosynthetic activity and productivity of intertidal macroalgae: in situ measurements, from thallus to community scale. Aquat Bot 123:6-12

Niklas KJ, Enquist BJ (2002) On the Vegetative Biomass Partitioning of Seed Plant Leaves, Stems, and Roots. Am Nat 159:482-497

Paul KI, Roxburgh SH, England JR, Ritson P, Hobbs T, Brooksbank K, Raison RJ, Larmour JS, Murphy S, Norris J, Neumann C, Lewis T, Jonson J, Carter JL, McArthur G, Barton C, Rose B (2013) Development and testing of allometric equations for estimating above-ground biomass of mixed-species environmental plantings. For Ecol Manag 310:483-494

Perkol-Finkel S, Airoldi L (2010) Loss and Recovery Potential of Marine Habitats: An Experimental Study of Factors Maintaining Resilience in Subtidal Algal Forests at the Adriatic Sea. PLoS ONE 5:e10791.

Poorter H, Niklas KJ, Reich PB, Oleksyn J, Poot P and Mommer L (2012), Biomass allocation to leaves, stems and roots: meta-analyses of interspecific variation and environmental control. New Phytol, 193: 30-50

Sack L, Grubb PJ, Marañón T (2003) The functional morphology of juvenile plants tolerant of strong summer drought in shaded forest understories in southern Spain. Plant Ecol 168:139-163

Santelices B, Hormazábal M, Correa J \& Flores V (2004). The fate of overgrown germlings in coalescing Rhodophyta. Phycologia43:346-52.

Scrosati R, DeWreede RE (1997) Dynamics of the biomass-density relationship and frond biomass inequality for Mazzaella cornucopiae (Rhodophyta, Gigartinaceae): implications for the understanding of frond interactions. Phycol 36: 506-516

Scrosati R (2005) Review of studies on biomass-density relationships (including self-thinning lines) in seaweeds: main contributions and persisting misconceptions. Phycol. Res. 53:224-33

Scrosati R (2006) Length-biomass allometry in primary producers: predominantly bidimensional seaweeds differ from the "universal" interspecific trend defined by microalgae and vascular plants. Can J Bot 84:1159-1166

Tait LW, Schiel DR (2011) Dynamics of productivity in naturally structured macroalgal assemblages: importance of canopy structure on light-use efficiency. Mar Ecol Prog Ser 421:97-107

Vadas, Sr. RL, Wright WA, Beal BF (2004) Biomass and Productivity of Intertidal Rockweeds (Ascophyllum nodosum LeJolis) in Cobscook Bay. Northeast Nat 11:123142 
Vaz-Pinto F, Martínez B, Olabarria C, Arenas F (2014) Neighbourhood competition in coexisting species: The native Cystoseira humilis vs the invasive Sargassum muticum. J Exp Mar Biol Ecol 454:32-41

Warton DI, Wright IJ, Falster DS, Westoby M (2006) Bivariate line-fitting methods for allometry. Biol Rev 81:259-291

Watt CA, Scrosati RA (2013) Bioengineer effects on understory species richness, diversity, and composition change along an environmental stress gradient: experimental and mensurative evidence. Estuar Coast Mar Sci 123: 10-18 
Table 1 Length-biomass relationships of macroalgal species collected in Brittany (NW France). Power equation: DW $=\mathrm{a} \times \mathrm{X}^{\mathrm{b}}$.

\begin{tabular}{|c|c|c|c|c|c|c|c|c|}
\hline Species & $\begin{array}{l}\text { Date of } \\
\text { sampling }\end{array}$ & $n$ & $\begin{array}{l}\text { Mean total } \\
\text { length }(\mathrm{cm})\end{array}$ & $\begin{array}{c}\text { Total } \\
\text { length } \\
\text { range }(\mathrm{cm})\end{array}$ & $\begin{array}{l}\text { Explanatory } \\
\text { variable }\end{array}$ & $\mathrm{a}$ & b & $\mathrm{R}^{2}$ \\
\hline $\begin{array}{l}\text { Chondrus crispus \& } \\
\text { Mastocarpus stellatus }\end{array}$ & $\begin{array}{l}\text { April-May-July- } \\
\text { Oct. }\end{array}$ & 66 & 10.02 & $3.5-16$ & $\mathrm{LC}^{2}$ & 0.0034 & 0.8259 & 0.93 \\
\hline Chondrus crispus & May & 35 & 8.70 & $3.5-13$ & $\mathrm{LC}^{2}$ & 0.0006 & 1.0318 & 0.95 \\
\hline Mastocarpus stellatus & April-July & 31 & 11.52 & $9-16$ & $\mathrm{LC}^{2}$ & 0.0067 & 0.7493 & 0.93 \\
\hline Fucus serratus & April-Oct. & 60 & 36.50 & $8-70$ & $\mathrm{LC}^{2}$ & 0.1763 & 0.5996 & 0.92 \\
\hline Fucus vesiculosus & Nov. & 48 & 41.44 & $13-117$ & $\mathrm{LC}^{2}$ & 0.0188 & 0.8028 & 0.87 \\
\hline Himanthalia elongata & March-June & 65 & 79.58 & $8-232$ & $\mathrm{~L}$ & 0.0319 & 1.2878 & 0.77 \\
\hline Himanthalia elongata & $\begin{array}{l}\text { March-June- } \\
\text { Aug.-Oct. }\end{array}$ & 75 & 98.20 & $8-281$ & $\mathrm{~L}$ & 0.0005 & 2.2323 & 0.81 \\
\hline Palmaria palmata & July-Oct. & 40 & 29.73 & $10-65$ & $\mathrm{LC}^{2}$ & 0.0006 & 1.4183 & 0.91 \\
\hline Saccharina latissima & April & 30 & 97.90 & $22-214$ & $\mathrm{~L}$ & 0.0155 & 1.3587 & 0.95 \\
\hline Ulva sp. & Oct. & 37 & 21.10 & $2-87$ & Lw & 0.0077 & 0.8921 & 0.93 \\
\hline
\end{tabular}

Table 2 Mean water content of macroalgal species collected in Brittany (NW France).

\begin{tabular}{lccccc}
\hline \multicolumn{1}{c}{ Species } & $n$ & $\begin{array}{c}\text { Mean water } \\
\text { content }\end{array}$ & $\mathrm{a}$ & $\mathrm{b}$ & $\mathrm{R}^{2}$ \\
\hline $\begin{array}{l}\text { Chondrus crispus \& } \\
\text { Mastocarpus stellatus }\end{array}$ & 66 & $74.4 \%$ & 0.257 & -0.034 & 0.96 \\
Chondrus crispus & 35 & $77.4 \%$ & 0.226 & 0.048 & 0.99 \\
Mastocarpus stellatus & 31 & $71.7 \%$ & 0.284 & -0.139 & 0.96 \\
Fucus serratus & 30 & $78.4 \%$ & 0.216 & 0.694 & 0.99 \\
Himanthalia elongata & 37 & $83.3 \%$ & 0.167 & -1.365 & 0.90 \\
Palmaria palmata & 40 & $87.3 \%$ & 0.127 & 0.777 & 0.95 \\
Saccharina latissima & 30 & $88.5 \%$ & 0.116 & 0.107 & 0.99 \\
\hline
\end{tabular}



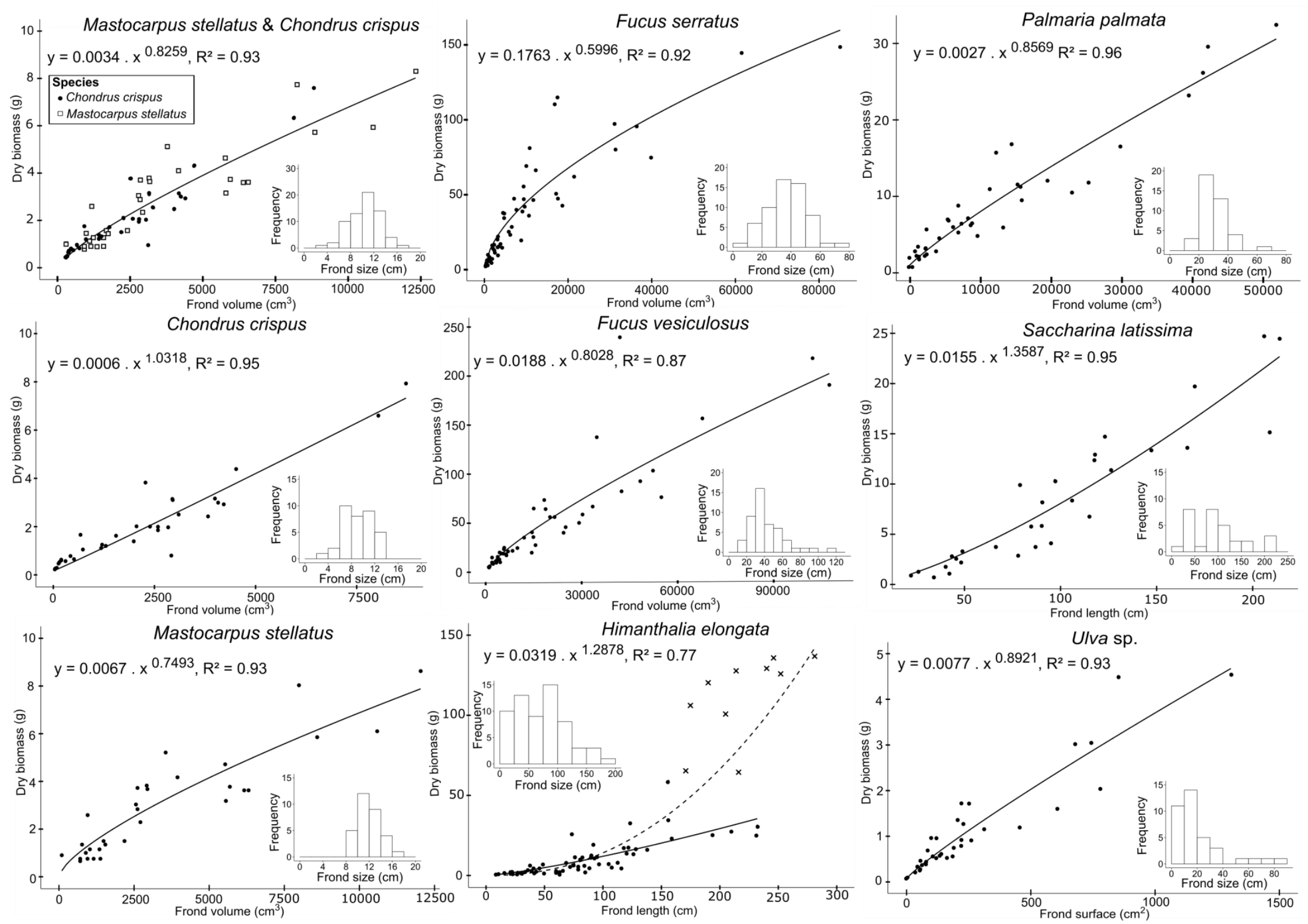

Fig. 1 Relationships between dry biomass ( $\mathrm{g}$ ) and biometric variables (in $\mathrm{cm}, \mathrm{cm}^{2}$, or $\mathrm{cm}^{3}$ ). For Himanthalia elongata, the plain line represents individuals harvested between March and June (i.e. the harvestable individuals truly harvested; round data points), while the dotted line also includes the older large individuals (cross-shaped data points) harvested in October. 
